\title{
Roots of Flight: Environmental Refugees in Latin America - A Response to Analysis by Homer-Dixon
}

\begin{abstract}
$+$
\section{Précis}

Les inégalités entre les pays du Nord et ceux du Sud n'ont cessées de se creuser depuis l'époque coloniale. Les politiques économiques imposées par le Nord en sont les principales causes. Cet article tente de démontrer que la croissance démographique et la diminution des ressources ne sont pas les principaux stimulants des mouvements des réfugiés et des conflits dans les pays $d u$ Tiers monde et en particulier ceux de l'Amérique latine. Ceux-ci sont plutôt liés à la politique foncière qui est dictée par les élites locales, les collaborateurs étrangers et la politique économique globale basée essentiellement sur les intérêts occidentaux.
\end{abstract}

\section{Introduction}

Fast becoming a standard term in migration research, "environmental refugees" denotes people who are forced to flee their home states because of environmental disaster and/or violence resulting from environmental degradation. A sharp increase in this type of migration is expected over the next fifty years, as the effects of global warming, ozone depletion, energy overconsumption, deforestation and air and water pollution take their toll on a fragile planet. As with most other environmental phenomena, however, identifying the source of these refugee flows has been a highly politicized and very misleading process.

Social scientist Thomas F. HomerDixon, for example, is considered to be a cardinal authority on this emerging field of research, and his arguments are generally touted as "progressive" by

Andil Gosine is majoring in Environmental Studies, and Latin American \& Caribbean Studies, and is a student in Refugee and Immigration Studies at CRS, York University.

\author{
Andil Gosine
}

fellow academics. He argues that the scarcity of natural resources is chiefly responsible for conflict resulting in the creation of environmental refugees (Homer-Dixon 1994, 5). Furthermore, he identifies three main sources of natural resource scarcities: a limited definition of "environmental change," the "unequal social distribution of resources," and population growth (ibid., 8)

But evidence from case studies in Latin America point to a different explanation. Contrary to HomerDixon's main theses, the experiences of indigenous peoples in Central and South America reveal that the manipulation of resources by external forces, not resource scarcity, is responsible for the apparent creation of environmental crisis. Consequences of historical and contemporary local and global power relations, such as colonialism, neocolonial economics and a misguided development process, are the actual stimulators of refugee flight.

While Homer-Dixon's widelypublicized analysis has stimulated much-needed debate on actual causes of refugee flight, some of his work can also be interpreted as merely rehashing misconstrued and misleading explanations of the causes of environmental degradation, poverty and conflict. Instead of questioning some of the basic ideologies which have historically framed international responses to refugee crises, his arguments often work in support of the approaches he claims to criticize. Indeed, the reactions of governments and agencies, such as the United Nations High Commission on Refugees (UNHCR), to refugee situations also expose a global system which fails to acknowledge the most significant, underlying roots of flight for these refugees, and which offers little support for these victims of environmental crisis.
Particularly in the North, some researchers and environmental advocacy groups have accepted the supposedly indisputable fact that people have been forced into poverty, environmentally-induced conflicts, and, ultimately, to take flight for survival because resources are in short supply. The invalidity of this assumption becomes apparent upon consideration of the political context of Latin America's most significant resource: land. An understanding of the social, economic and spiritual relationship between natural land and indigenous peoples-and the impact of the current global economic order on this relationship-is central to understanding the roots of environmental crisis and refugee flight in Latin America. "We think of the earth as the Mother of man," Nobel Peace laureate and indigenous leader Rigoberta Menchu suggests: "our parents tell us: 'Children the earth is the mother of man because she gives him food"' (Menchu 1991, 56). Colonization was a genocidal process which not only confiscated peoples' original environment, but also attempted to diminish their relationship with the natural world, cultural heritage and socioeconomic structures. Since the first European voyages to the Americas, indigenous peoples have been struggling not just to reclaim what was seized by colonisers, but to simply hold on to whatever land remained in their control. Land disputes are at the root of conflict in most Latin American countries today.

An April 1992 march in Quito, Ecuador protested the government's inability to settle land disputes (Macas in Collins 1992, 1). Between 1981 and 1983, a 'pacification' project undertaken by the Guatemalan government had sent a flood of refugees into Mexico, as the repressive regime seized indigenous land and placed it in 
foreign control (Weinberg 1991, 4647). In Mexico, members of the Ejercito Zapatista de Liberacion Nacional (EZLN), the collection of indigenous farmers who organized the January 1, 1994 Chiapas rebellion, chanted, "From the coast to the mountains, the struggle is for the land" (Ross 1994, 3). An Americas Watch report on Brazil noted that the fight for land in rural areas has led to a "spiral of violence" in which those responsible enjoy total impunity (July 9, 1992). As further examination of these cases will reveal, conflict did not stem from the scarcity of this container of natural resources, but from oppressive government action which resulted in the seizure of land from peasant farmers and indigenous communities to service Northern corporate interests.

In Guatemala, Mayan Indians were moved from lands so that the transnational corporation Del Monte could have new cultivation fields, and cattle grazing for hamburger beef production could expand (Weinberg 1991, 43). The military offensive to carry out this removal was financed by Israel and the United States, and the offensive eventually wiped out of tens of thousands of Mayans and produced a refugee population of over one hundred thousand (Hooks 1993, 61). In 1991, 2.1 percent of Guatemala's population still controlled 80 percent of the agricultural land (ibid., 152). Similarly, land is not scarce elsewhere in Latin America, but access to it, and the natural resources it holds, is limited to those with political clout. Meanwhile, disempowered peoples must struggle for rights to access to their land. The resulting conflict often forces these very people to revert to refugee flight for survival.

\section{Environmental Change}

Homer-Dixon identified six types of environmental change which he concluded were plausible causes of violent inter-group conflict resulting from resource scarcity and leading to refugee flight: greenhouse-induced climate change, stratospheric ozone depletion, degradation and loss of agricultural land (but not specifically, loss of land rights), deforestation, depletion and pollution of fresh water supplies, and depletion of fisheries (Homer-Dixon 1994, 6). All of these "changes" are primarily attributable to the activities of a capitalist global economy that serves the North (see Susan George, 1976, 1986). While environmental changes are indeed feasible sources of refugee flight, this list does not adequately indicate the underlying causes of environmental degradation and conflict. By concentrating on changes that seem abstract (ozone depletion, greenhouse effect) or locallyinduced (deforestation, water pollution), insufficient emphasis is placed on the more influential and obvious sources of inter-group conflict of every kind in Latin America. John Walton suggests

The state in Latin America was dependent on growth within the norms of dependent capitalism. That meant uneven development, prosperity for comprador classes, agribusiness, industry and services linked to transnational corporations; relative impoverishment for workers, independent producers, peasants and tenants. (Walton 1989, 305-6)

Similarly, environmental destruction which resulted in the displacement of people, conflict and refugee flight has been virtually created by the application of intensive capitalism, not through voluntary initiatives taken by the local population or by some abstract "natural" reaction.

The Zapatistas in Mexico, for example, argued that the North American Free Trade Agreement (NAFTA) "was a death certificate for indigenous peoples of Mexico" because the impact of free trade would wipe out the economic, social and cultural base of their communities, following the collapse of prices of the area's major commodities (timber, coffee, corn) (Americas Watch, March 1, 1994, 3). Mechanized agricultural processes which are sold as part and parcel of the development process also greatly accelerate land degradation. Environmental accounts on the impact of free trade in Mexico indicate that economic initiatives, such as the setting up of Export Processing Zones (EPZs), are responsible for the very hazardous levels of pollution in areas such as the Maquilladoras; the "environmental changes" result directly from economic constraints.

Liberal economic policies benefit local elites and TNCs at the expense of marginalized peoples. As recently as mid-February, 1995, press reports outlined the "bombing of Mayan villages ... raping of women and killing of children" by the Mexican army, in the government's bid to crush the Zapatista resistance movement (Toronto Star, February 13, 1995, p. A 13). An Americas Watch report concluded, "conflicts over land tenure and the use of natural resources are a chronic problem in Chiapas" (ibid.,5). As their report indicated, the lack of resources wasn't the main issue, but rather, the use of the available resources consequently created political strife.

Free trade is by no means the only contributor to conflict in Chiapas. As in other regions of Latin America, the impact of the debt crisis and the subsequent application of Structural Adjustment Programmes (SAPs) by the International Monetary Fund (IMF) have added to the economic woes of the poor, and increased environmental degradation and conflict. Walton describes these skewed strategies, as imposed by Northern-controlled agencies:

Guided by the potent combination of neoclassical economic orthodoxy and the interests of the advanced nations, the IMF prescribed a clear and remarkably uniform adjustment policy aimed at promoting market economies geared to export production. (Walton 1989, 306)

From India to Mexico, the application of SAPs to enhance agro-export industry has caused deforestation for cattle grazing and overworking of agricultural lands for greater crop harvest (Shiva and Mies 1993, 233-35). SAPs have also promoted the growth of "dirty" industries throughout the Third World, as transnational corporations concurrently pollute the environment and institute abhorrent labour 
conditions.SAPs ensure that resources are not geared to sustain the local population but to enhance the economic growth of local elites and, ultimately, their foreign conspirators.

The manipulation of natural resources to serve economic interests of powerful actors are clearly at the root of conflict and environmental crisis in Latin America. The "environmental changes" Homer-Dixon describes play a secondary role. Although these changes are immediate stimulators of conflict and must be rectified, they are by-products of a more effective, underlying cause of conflict and migration: an inequitable global political economic system.

\section{Population Growth}

The most frequently distorted explanation of environmental crisis has also been mistakenly applied to the case of environmental refugees. Certainly, the weakest link in Homer-Dixon's analysis is the one he makes between resource scarcity and population growth. Choosing to reflect, rather than offer valid criticism of, a traditional, misleading Northern perspective, Homer-Dixon insists that "bulging populations and the resulting land stress may produce waves of environmental refugees" (HomerDixon 1991, 77)

Since Thomas Malthus' Essay on Population was first published in 1798, overpopulation propaganda has been used as an effective tool to blame the poor, and excuse the rich, for the former's state of poverty. The United States government led the drive to support population control programmes in the Third World, its contribution to family planning strategies exceeding $\$ 3$ billion over the last thirty years (USAID 1994, 23). Uruguayan writer Eduardo Galeano noted the main reason behind this disturbing endeavour:

[The United States'] aim is to justify the very unequal income distribution between countries and social classes, to convince the poor that poverty is the result of the children they don't avoid having, and to dam the rebellious advance of the masses ... in
Latin America, it is more hygienic and effective to kill guerrilleros in the womb than in the mountains or the streets. (Galeano quoted in Weinberg 1991, 149-50)

Malthus, however, has sprung a number of influential successors who are in firm control of the institutions which establish global political economy. At the 1994 Cairo Conference on Population and Development, feminists did not only have to face demographers, population agencies and the Vatican and its allies, but also environmentalists from the North who promoted the idea that sooner or later resources will be wiped out by population growth (Correa and Petchesky 1994, 10). As Susan George determined in the 1970s, overpopulation itself is a mythical concept, void of hard scientific evidence, but "so much garbage has been printed, so much bad theory circulated" that it is commonly accepted as a scientific principle (George 1976, 59).

Homer-Dixon is one such circulator of "bad theory." He points to the 1970 s subsistence crisis in the Southern highlands of Peru, which gave rise to the Sendero Luminoso (Shining Path) movement, as evidence of the effects of population growth:

The department of Ayacucjo saw density increase from 8.1 people per square kilometer in 1940 to 12.1 in 1980. Cropland availability dropped below .2 hectare per capita. These densities exceed sustainable limits, given the inherent fragility of the region's land and prevailing agricultural practices. (Homer-Dixon 1993, 29)

But, as is the case for all of the situations already cited, population growth did not cause poverty or loss of agricultural lands in Peru. The resulting violence, which has produced a significant number of refugees since the original clashes between the Peruvian government and the Shining Path, was rooted in land distribution, or rather, the lack of fair land distribution.

As Cynthia McClintock observed, the southern highlands are poorly suited for agriculture but the valleys below are very fertile lands (McClintock 1989,55). Instead of redistributing this area to the peasant farmers, however, the government uses it for export-based agricultural industry, to service debt and foreign market needs (ibid.). Half of Peru's arable land is located in the coastal region of Montana, but rather than use this area as a source of sustenance for local populations, economic activity is centred on the processing of forestry products and oil for export (New Giolter Multimedia Encyclopedia 1994).

The Pan American highway, used as a major route for export-oriented, transnational industry, spans across much agricultural and previously forested land from Chile to Alaska, crossing through Peru (Weinberg 1991, 131). Interestingly, the Darien tropical forest in Panama has been labelled 'the Darien Gap' because it is the only broken link in the transnational highway. Suggestions are that this crucial natural park is on the brink of destruction because of American pressures to "fill the gap." The construction of highways in Central and South America has resulted in the violent displacement of peoples and the synchronous destruction of the natural environment. Land and food are available in Peru: they are resources which have been manipulated by the elite, not which have become scarce because of the growth of the oppressed.

The contradictions in the overpopulation establishment are baffling. Neomalthusian ecologist Paul Ehrlich, for example, has written in horror that "El Salvador, a country about the size of Massachusetts, has 4.5 million people today" (Ehrlich et al. 1979, viii). However, Massachusetts itself has a population of 5.8 million (Hartman in Weinberg 1991, 153)! Similarly, wh. le Homer-Dixon determined that a population density of $\mathbf{1 2 . 1}$ per square kilometre in Peru's Southern highlands was "not sustainable," other areas in the world have been able to sustain far more people with very little agricultural land space. New York City, for example, has a population density of 147.1 per square kilometer,

Refuge, Vol. 15, No. 2 (April 1996) 
with small areas in it holding densities which surpass thousands $/ \mathrm{km}^{2}$ (1990 census, New Giolter Multimedia Encyclopedia 1994). But liberal economics and free trade arrangements have made food produced in Latin America more accessible to people a continent away than where the food itself is grown.

What isn't as confusing as Malthusian ideology or explanations however, is the reason for emphasising the "hazards" of population growth. Ehrlich warns that "too many people" leads to "too little food" and "a dying planet" (Quoted in Sen 1994, 66). Similarly, Homer-Dixon argues that "a bulging population (will produce) environmental refugees that spill across borders with destabilizing effects on the recipient's domestic order and on international stability" (On the Threshold, Fall 1991, 77).

The purpose of these xenophobic comments, much like the purpose behind the promotion of overpopulation propaganda, is to reinforce a global system of economics which allows the North to "have its own cake and eat the South's too." The North wants to further industrialize and still use the South as a source for food and environmental sustenance; and while this system results in conditions which force people to leave their home states, the North refuses to open their borders to accept the "by-products" of their own processes. By suggesting that overpopulation results in refugee creation, the North is able to relieve itself of its responsibilities and in turn blame the South for its misery.

To his credit, Homer-Dixon acknowledges that population growth alone does not cause conflict. But by concentrating on population growth as a major contributor to so-called "environmental" conflict, he is effectively advocating a solution for the "problem" of overpopulation. Population control programmes have not only been futile anti-poverty mechanisms, but they have also proven to be a source of violence and human rights abuses. In Latin American countries where over $80 \%$ of the women have been sterilized, poverty has been exacerbated not alleviated, and women's reproductive rights have been grossly abused (Shiva and Mies 1989, 289). Brazil's birth rate has declined by over $50 \%$ in 20 years-a feat the Northern countries took several centuries to achieve-but there are more poor street children and more criminal violence today than in the 1970s (ibid.) Family planning is a damaging solution for the wrong problem.

A newspaper report about the May 27, 1990 occupation of the Santo Domingo Cathedral in Quito, Ecuador effectively contextualizes the mythical population/conflict relationship and the need for new strategies which move beyond population propaganda. Quito's daily paper, El Comercio, called the occupation "the sixty uprising," the others having taken place in 1578, 1599, 1615, 1766 and 1892 (Field 1991, 40). Regardless of population growth, the key issue here remained the same over the centuries: inequitable land distribution resulting from colonial policy and continued through capitalist economics dictated by the North.

\section{Resource Distribution}

Homer-Dixon accepts that "unequal social distribution of natural resources" is a major contributing source of scarcity-induced violence (HomerDixon 1994, 7). Using the familiar pie analogy, he theorizes that:

reduction in the quantity or quality of a resource shrinks the resource pie, while population growth divides the pie into smaller pieces for each individual and unequal resource distribution means that some groups get disproportionately larger slices. (ibid., 9)

He summarizes all his arguments into one tidy explanation that doesn't appear far-fetched or unreasonable. Yet even the admittance that distribution inequities is an important influence on environmental conflict is also too limited because it neglects to sufficiently explore the reasons for the unequal resource distribution. Certainly, the acknowledgement of resources being unequally divided negates the the- sis that "resource scarcity" leads to conflict; "unequal social distribution of resources" implies that there are availablenatural resources which have been manipulated. A better approach would refrain from over-simplistic illustrations which conceal the complex web of influences on access to resources.

The "cutting" of the resource pie is not exempt from the impact of the colonial tradition of using the South to supply the resources to build the North. E. Bradford Bruns describes the impact of colonialism of Latin America's post-independence economic development:

similar to the well-established patterns of Latin America's past, the export sector of the economy remained the most active ... More often than not, foreigners, with their own agendas dominated that sector. Following the colonial pattern, the economy in general depended to a large degree on the export sector for its growth and prosperity. (Burns 1990, 137).

This dependency relationship confined Latin American countries to a position of continually supplying Europe and North America with natural resources. Despite the end of official colonial rule, land remained in the hands of colonists in most of Latin America. Prior to land reform in the late 1980s, 2 percent of El Salvador's population controlled 60 percent of the state's territory; before the 1979 revolution in Nicaragua, the Somoza family alone owned 23 percent of the land (Weinberg 1991, 152). The colonial legacy remained intact.

The "pie-sharing" process HomerDixon describes is also not exempt from political circumstances of the time period. The East-West/capitalistcommunist tensions provided an excuse for the United States' intervention against fairer land reform in Guatemala. In 1953, elected Guatemalan President Jacobo Arbenz seized nearly 500,000 acres from the American corporation United Fruit Company to redistribute to landless peasants (Burns 1990, 267). Since Arbenz feared attack from the country's more conservative 
neighbours-Honduras and El Salvador, both closely tied to the U.S.-he accepted defensive military aid from Poland. To the U.S. State Department, "its arrival served as final proof that Guatemala had fallen under Communist control," despite Arbenz having been democratically elected with a large percentage of popular support (ibid., 270). In 1954, the Arbenz government fell to a U.S. coup (ibid.) Since then, landless peoples have been forced to seek asylum in countries such as Canada; they are refugees whose rights to live in their natural environment have been grossly infringed.

Not only are natural resources and wealth unequally distributed in Latin America, but so too is the experience of citizenship. Refugees are created by national and international state policies which reject the notion of equal citizenship or equal environmental rights for all people. Through the maintenance of colonial government structure and Eurocentric educational, religious and other socialization methods, indigenous peoples' cultural and social rights have not been respected in Latin America. In Venezuela, the only four remaining ethnic groups of indigenous peoples have suffered from ongoing incursions by petroleum, mineral and mining industries on their lands near the Colombian border (Latinamerica Press, February 18, 1993, 5). A colonial system of land division has also projected Eurocentric conceptions of citizenship on Venezuelan Indians. In contrast to the current system, Karina Indian Jose Poyo argues that "rights to the land should be recognized and should be granted as a collective right," and that, "our cultural preservation, unity as a people and the chance for the survival of our identity and traditions depend on this tradition" (ibid.).

\section{International Response}

As previously mentioned, HomerDixon's approach to analysis of environmental conflict and refugee flight is generally more progressive than those taken by Northern governments and international organizations. His mod- els at least identify the relationship between environmental degradation and conflict and, most importantly, acknowledge the legitimacy of environmental refugees and the need to address their situations. Failure to recognize or respond to the root causes of environmental refugee flight is frighteningly evident in the international response to this phenomena.

Though primarily responsible for the creation of environmental degradation and the manipulation of natural resources, Northern countries have refused to open their borders to refugees created from this process or address the underlying, long-term causes of flight. In 1995, for example, the Canadian government abandoned any type of "genuine aid" delivery by moving further to make "aid" transfers a system of Canadian market expansion, adding to, rather than alleviating, problems in the Third World. Tougher Canadian immigration laws will also undoubtedly affect refugees, and measures to remove refugees' access to more social services signal the dawn of the "de facto" refugee system already in place in Europe.

Since the United Nations Charter on Refugees remains essentially a Eurocentric construction, it is not an adequate reference in dealing with the situation of environmental refugees from Latin America. An ideal definition of a refugee would be more similar to the approach taken by the Organization for African Unity. Their Charter definition better reflects the reality faced by refugees today:

every person who, owing to external aggression, occupation, foreign domination or events seriously disturbing public order in either part or the whole of his country of origin or nationality, is compelled to ... seek refuge in another place outside his country of origin or nationality. (Gallagher et al. 1989, 338)

This broader definition is more pertinent to the situations faced by refugees in the South. Latin American environmental refugees have been able to apply under the UN Convention since they are usually also political refugees, but the fluid nature of politics and its interpretation may endanger their claims.

Recognition of "environmental rights" as "political or social rights" the right to access to and use of one's natural environment-in the U.N. Convention or by governments, is necessary to protect these refugees from the impact of everchanging political preferences in host states.

The individualization of the refugee process globally is also problematic. Whereas the Canadian IRB, for example, has designed a system which places the burden of proof on a single person, an environmental refugee's situation is created by a complex web of several interacting factors which an individualized system may not consider. Furthermore, immigration and economic policies, which are essentially patriarchal, affect women adversely, and must be challenged and changed; in Guatemala, for example, Mayan women have been at the forefront of resistance movements, and have suffered the brunt of environmental degradation.

Certainly, refugee response mechanisms only deal with the immediate implications of crisis. The underlying causes of refugee flight identified in the paper must also be addressed. The North can begin by listening to its own discourse about the perils of ozone depletion; deforestation, and the greenhouse effect. Environmental degradation will radically alter the state of the world, but the North cannot expect the South to limit its numbers so that the latter's resources can continue to act as their supply source.

Inequities between the North and South, stemming from a colonial past, capitalist economic policies and $\mathbf{g}^{\mathbf{}} \mathrm{o}$ balization, have to be corrected. Countries in the North are obliged to open their borders as some token compensation for the wrath of colonialism and dependency economics. Although his suggestions are not as far-reaching as they should be, Homer-Dixon agrees that the North bears a responsibility to tackle the roots of refugee flight-even for its own security; he realizes that the 
"rebellious" spirit Eduardo Galeano described earlier will not be calmed forever.

\section{Conclusion}

What is most frustrating about discussions on root causes of environmental crisis, conflict or refugee flight is that they are the same root causes of poverty, inequity, social conflict and other ills discussed decades ago. In the 1970s, Third World nations called for changes to rectify unequal NorthSouth economic and political relations. In the 1990s, many of them still do. In the 1986 foreword to a revised version of her 1976 book, How the Other Half Dies, Susan George admits that the same root causes of crisis she identified at least ten years earlier still persisted: application of foreign technology, agribusiness, corporate greed, overconsumption and so on. I expect her analysis to be as relevant in 1996. But the World Bank, IMF, United Nations and other Northern-controlled institutions have failed to move away from traditional paradigms and continue to apply unsuitable solutions.

In Latin America, population growth and resource scarcity are not the main stimulators of refugee flight or conflict. In Guatemala, El Salvador, Brazil, Mexico, and elsewhere, "the root of conflict lies in access to land" (Weinberg 1991, $x$ ). Access to land is dictated by local elites, foreign collaborators, the global political economy and the area's colonial history. Attempts to access land-their environment-has caused the death of hundreds of thousands of indigenous peoples, and created even more refugees. While Mayans in Chiapas, Guatemala and El Salvador continue to rebel against an oppressive system, we in the North must also provide resistance against economic and political oppression of the South by the North, against closed borders to refugees, and end our own complacency with injustice.

\section{References}

Americas Watch. 1994. "The New Year's Rebellion: Violations of Human Rights and
Humanitarian Law during the Armed Revolt in Chiapas, Mexico." Americas Watch. Vol. IV, No. 3. March 1. Washington: Human Rights Watch.

Americas Watch. 1992. "Condemnation of Land-Related Violence." Latin American Regional Reports: Brazil Report. July 9.

Burns, E. B. 1990. Latin America: A Concise Interpretive History. New York: Oxford Press.

Collins, J. 1992. "Education Indians march to capital." Latinamerica Press. Vol. 24, No. 16. April 30.

Correa, S. and Rosalind Petchesky. 1994. "Exposing the Numbers Game." Ms. Vol. V., No. 2, September. New York: Lang Communications.

Ehrlich, Paul, Loy Bilderback, and Anne $\mathrm{H}$. Ehrlich. 1979. The Golden Door: International Migration, Mexico and the United States. New York: Ballantines Books.

Field, L. 1991. "Ecuador's Pan Uprising." NACLA Report on the Americas. Vol. 25, No. 23, December.

Gallagher, D., Susan Forbes Martin, and Patricia Weiss-Fagen. 1989. "Temporary Safe Haven." International Migration and Refugees, edited by Gil Loescher and Laila Monahan. New York: Oxford Press.

George, Susan. 1986. How the Other Half Dies. London: Penguin Books.

George, Susan. 1976. How the Other Half Dies. New York: Penguin Books.

Hartman, Betsy. 1987. "Reproductive Rights and Wrongs." In War on the Land: Ecology and Politics in Central America, edited by B. Weinberg, 1991. London: Zed Books.

Homer-Dixon, T .F. 1994. "Environmental Scarcities and Violent Conflict: evidence from cases." International Security. Vol. 19, No. 1. Boston: Harvard College and M.I.T., July.

Homer-Dixon, T. F., Jeffrey Boutwell, and George Rathjens. 1993. "Environmental Scarcity and Violent Conflict." Scientific American, February.

Homer-Dixon, T. F. 1991. "On the Threshold: Environmental Changes as Causes of Acute Conflict." International Security. Vol. 16, No. 2. Boston: Harvard College and M.I.T., February.

Latinamerican Press. 1993. "Venezuelan Indians link traditions to land." Latinamerica Press, February 18.

Hooks, M. 1993. Guatemalan Women Speak. Washington: EPICA.

Menchu, R. 1991. An Indian Woman in Guatemala. Washington: EPICA.

McClintock, C. 1989. "Peru's Sendero Luminoso Rebellion: Origins and Trajectory. Power and Popular Protest in Latin
America, edited by Susan Eckstein. Los Angeles: University of California Press.

New Giolter Multimedia Encyclopedia. 1994. 1990 Census.

On the Threshold. 1991. Fall.

Ross, J. 1994. "Land battles continue after Chiapas Uprising. Latinamerica Press. September 29.

Sen, A. 1994. "Population Delusions and Reality." The New York Book Review. New York.

Shiva, V. and Maria Mies. 1989. Ecofeminism. London: Zed Press.

The Toronto Star. 1995. February 13. Toronto: TORSTAR Publications.

USAID. 1994. USAID Strategies for Sustainable Development. Washington: USAID Publications.

Walton, J. 1989. "Debt, Protest and the State in Latin America." Power and Popular Protest in Latin America, edited by Susan Eckstein. Los Angeles: University of California Press.

Weinberg, B. 1991. War on the Land: Ecology and Politics in Central America. London: Zed Books. $\square$

Gender and Refugees: The following Working Papers on gender and refugees are now available.

Gottstein, Margit; Women Refugees and Asylum Policy in the Federal Republic of Germary: An Analysis of Aims and Results; (26 pages)

Green, Hollyn; Refugee Transition: A Unique Opportunity to Realign Women's Human Rights. (12 p)

Jacob, Andre and Levy, Joseph; The Integration of Two Groups of Women Refugees: Guatemilans and Bulgarians; (17 p)

laved. Nayvar; Refigee Women: Gender and Race Identities or "Cultural Difference" Observations and Reflections, (19 p)

Nyakabwa, Kabahenda and Lavoie, Carollne; Violence Against Women Refugees in the Hom of Africa, (22 p)

Roaldje Noelle, Nodjal, Experiences Gained in Exile. The Case of Women from Chad: $(15 \mathrm{p})$

Robinson, Phyllis, Whose Oppression Is This, 4hisury. (16\%)

Van Esteril, Permy. Sal, Lord of the Table: Sall Consumption in Lao PDR - Implications for IDD Control $(23 \mathrm{p})$

Papers may be ordered separately or as

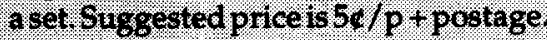
Please send your requests to: Gender Whit, ontre for Refigace Studies. York

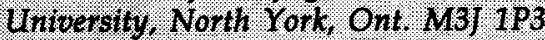
(emall, vgllesoyorkinca) 